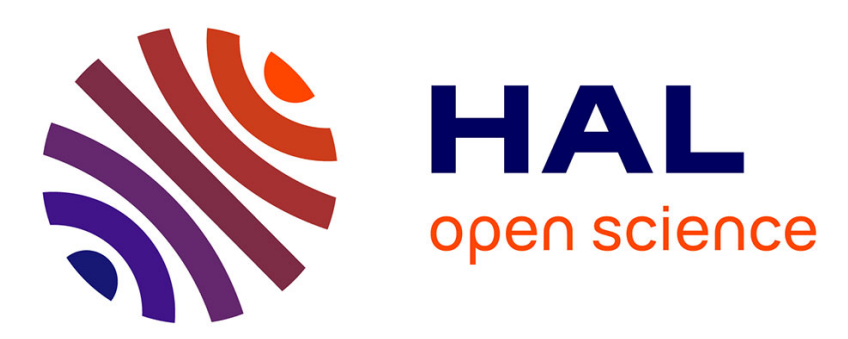

\title{
Financial Regulation in the Crisis Regulation, Market Discipline, Internal Control: The Big Three in turmoil
}

Jézabel Couppey-Soubeyran

\section{To cite this version:}

Jézabel Couppey-Soubeyran. Financial Regulation in the Crisis Regulation, Market Discipline, Internal Control: The Big Three in turmoil. International Economics, 2010, 3 (123), pp.13-30. hal00627436

\section{HAL Id: hal-00627436 \\ https://hal.science/hal-00627436}

Submitted on 13 Oct 2011

HAL is a multi-disciplinary open access archive for the deposit and dissemination of scientific research documents, whether they are published or not. The documents may come from teaching and research institutions in France or abroad, or from public or private research centers.
L'archive ouverte pluridisciplinaire HAL, est destinée au dépôt et à la diffusion de documents scientifiques de niveau recherche, publiés ou non, émanant des établissements d'enseignement et de recherche français ou étrangers, des laboratoires publics ou privés. 


\title{
FINANCIAL REGULATION IN THE CRISIS REGULATION, MARKET DISCIPLINE, INTERNAL CONTROL: THE BIG THREE IN TURMOIL
}

\author{
Jézabel Couppey-Soubeyran ${ }^{1}$
}

Article received on May 5, 2010

Accepted on September 9, 2010

\begin{abstract}
The financial crisis has revealed the dysfunction of all banking and financial regulatory mechanisms. Prudential regulation failed to prevent the meltdown. Market discipline neglected to send any warning signals. Internal control was seriously undermined by doubfful dealings, in France as elsewhere. Does the crisis call the big three into question? No regulation mechanism is omniscient, whether it be state, market or self-regulation. As such, none of three can operate without the other two, with the corollary that they can only function together. It means that spliting up the big three can therefore not be the answer to the crisis. By contrast, since each one of them has shown its weaknesses, the only solution is to work on reinforcing each one. Unfortunately there is no guarantee that the reforms go far enough.
\end{abstract}

JEL Classification: G01, G18, G21, G38

Key words: Prudential Supervision, Market Discipline, Internal Control,

Financial Regulation.

RéSUMÉ. La crise a révélé les failles de l'ensemble des mécanismes régulateurs de la finance mondiale : la réglementation prudentielle a échoué dans sa mission de prévention, la discipline de marché n'a pas envoyé les signaux d'alerte qu'on pouvait en attendre et le contrôle interne a été sérieusement écorné par des affaires retentissantes en France comme ailleurs. La crise remet-elle en question ce triptyque et condamne-telle à faire entièrement reposer la régulation financière sur la seule action des pouvoirs publics? Si l'on part du principe qu'aucun mode de régulation n'est omniscient, pas plus l'État que le marché ou l'auto-contrôle, alors aucun des trois ne peut fonctionner à l'exclusion des deux autres. Défaire ce triptyque ne peut donc pas constituer une réponse à la crise. Mais puisque chaque bras du triptyque a montré ses faiblesses, il convient de travailler au renforcement de chacun. À cet égard, il n'est toutefois pas garanti que les réformes aillent assez loin.

Classification JEL : G01, G18, G21, G38 Mots-clef : supervision prudentielle, discipline de marché, contrôle interne, régulation financière.

1. Corresponding author: Jezabel Couppey, Economist - Centre d'économie de la Sorbonne, University Paris 1 Panthéon-Sorbonne (couppey@univ-paris1.fr). 
The financial crisis, born in the summer of 2007 and still arguably alive in 2010, has revealed the dysfunction of all banking and financial regulatory mechanisms. Prudential regulation failed to prevent the meltdown. Market discipline neglected to send any warning signals - low risk premiums, high ratings. Internal control was seriously undermined in France by doubfful dealings such as the Société Générale, Caisse d'épargne and Madoff affairs on a larger scale. The big three are nevertheless the basis for today's financial regulation and this situation is the result of a slow process of evolution.

The reforms that gave rise to "financial safety nets" in the 1930s in the United States - e.g. the 1933 Banking Act - then in post-war Europe and in Japan were all initially inspired by the desire to replace dysfunctional market regulation. The resurgence of economic imbalances in the 1970s did, however, give financial operations a massive shot in the arm. Three factors brought about new financial needs and prompted the creation of new financial products and new markets: first, the petrodollars from the oil-price shocks, recycling surpluses from oil-producing countries; second, the unstable interest rates subsequent to post oil-price shock inflation and the monetary change in course in the United States in 1979 with Paul Volker's arrival as head of the Fed; and third, the fluctuating exchange rates related to the collapse of the Bretton Woods system in 1973. The boom in the capital market then automatically caused banking activity to evolve and the regulatory framework of the banking sector necessarily had to adapt accordingly. The new regulation, termed "prudential" (minimum capital requirement), set up from the end of the 1980s, no longer attempted to substitute for the market mechanisms, but rather to limit risk taking by banks. Market logic gradually found its place again in the banking sector, with the suppression of credit constraints, the liberalization of rates and the privatization of financial institutions among others, and held financial institutions to the relevant potential sanctions, such as investors' demand for profitability, threats of buyouts, and the variability of resource costs. Rising risks also made banks more sensitive to the need to manage risks and prompted bankers to adopt suitable evaluation and risk management tools. Along the way, internal control was developed to the extent that major international banks endeavoured to get international authorities to recognize the use of these tools. From the mid-1990s, the Basel Committee on Banking Supervision recommended authorizing banks to use their internal "value at risk" models to calculate their capital needs. As a result, the relationship between regulation, internal control and market discipline gradually grew stronger.

Does the crisis call the big three into question? Will it entail massive backtracking in regulation? In order to answer these questions, let us begin with a simple principle put forward by the 2009 Nobel economics Prize Oliver Williamson in analyzing governance modes. No regulation mechanism is omniscient, whether it be state, market or self-regulation. As such, none of three can operate without the other two, with the corollary that they can only function together. Splitting up the big three can therefore not be the answer to the crisis. By contrast, since each one of them has shown its weaknesses, the only solution is to work on reinforcing each one. In that view, the paper proceeds as follows. Section 1 deals with the weak points of prudential regulation and discusses the progress that we can expect from the future Basel 3 
agreements. In Section 2, we underline the weak points of internal control and we try to show that the fault line does not reside in the linkage between internal control and supervision as such, but rather in the evolution of internal control during recent years. Section 3 focuses on the weak points of market discipline, stressing problems and the way forward. Section 4 is the conclusion.

\section{Prudential Regulation: the Weak Points}

Even though we learn from crises, and more particularly from financial crises, they come back again and again, as Paul Krugman explains in "The Return of Depression Economics" (1999) - but always from where we least expected them. All throughout the 1980s, regulatory authorities tried to reach an agreement in the Basel Committee on how to make banks comply with a solvency standard. The first Basel agreements in 1989 eventually managed to establish the Cooke ratio - capital/risk-weighted assets $>8 \%$ - after long years of discussion. Throughout the 1990s, prudential authorities continued to focus on solvency, initially broadening capital standards to market risks, then refining credit risk measurement and extending risk measurement to operational risk (the Basel 2 agreements, which entered into force only in 2007-2008). In this way, the banking establishment's solvency improved over these years. Predictably however, the financial crisis that began in the summer of 2007 did not stem from insolvency issues.

The faults in prudential regulation revealed by the financial crisis - which we propose to focus on here - involve three aspects:

- inadequate attention to illiquidity risks,

- too little asset leverage constraint,

- credit procyclicality, compounded by accounting and prudential standards.

\section{The illiquidity risk}

From the 1980s on, regulators' attention focused on the solvency of banks, which sought tools that would enable them to reduce the regulatory cost of capital, in order to "manage" regulatory constraint as well as possible. This is the context where securitization and credit derivatives developed, allowing banks to reduce the denominator of the Cooke ratio to a minimum. With the help of this circumvention, bank balance sheet solvency - as evidenced by regulatory ratios - improved from 1990 to 2000. By contrast, during this same period, balance sheet liquidity as measured by the share of liquid assets steadily broke down. Charles Goodhart (2008) cites an article by Tim Congdon where he mentions the fact that British banks in the 1950s held a large percentage of liquid assets, around 30 percent of their balance sheet, in the form of treasury bonds or short-term public securities. Fifty years after, they hold no more than 1 percent. The deterioration in liquidity did not raise any concern, since asset liquidity has habitually become associated more with the dynamism of a given market than with the short maturity per se of the assets. Yet it is the incapacity of certain financial institutions to be able to mobilize liquid assets that caused the difficulties. Certain 
assets supposedly "easy" to sell owing to the dynamism of their secondary market before the crisis simply saw their market literally devastated by the crisis.

Since then, liquidity has been an important "work site" for regulators, but it is nevertheless a difficult one. International negotiations on the subject failed in the 1980s. The crisis has unquestionably underscored the importance and urgency of regulation, but what still remains to accomplish is to reconcile widely varying national practices and impose a measure which will, however, be simple. Several routes can be envisaged. The transformation of maturity can be limited by forcing banks to match a percentage of the resources they collect with assets of the same maturity or impose a minimum ratio of liquid assets/total assets in the balance sheet. There is a trade off between these two possible approaches, since limiting transformation reduces the requirement for liquid assets and, on the contrary, having more liquid assets allows less constraint on transformation. What remains to be found is the optimum relationship between these two types of requirement. It will also be necessary to achieve a harmonized definition of liquid assets. To this end, will it be necessary to consider the maturity, the degree of standardization, the secondary market's volume of activity for the relevant assets, or some other criterion? Liquidity remains a complex concept and this will inevitably pose a problem in agreeing on a harmonized definition internationally.

In the Consultative Document (2009) preparing the upcoming Basel agreements (Basel 3), the Basel Committee proposed two ratios: a Liquidity Coverage Ratio (LCR) and a Net Stable Funding Ratio (NSFR). In both cases, the idea is to reinforce the capacity of banks to withstand shocks. The first ratio would make banks hold a stock of high-quality liquid assets enabling them to "survive" their commitments for 30 days, while the second is a structural liquidity ratio valid over a longer timeframe that would force banks to hold more stable resources (one year):

$L C R=$ Stock of high-quality assets/net cash oufflows over a 30 day time period $>100 \%$ NSFR $=$ Available amount of stable funding/required amount of stable funding $>100 \%$

The liquidity "work site" does not only raise problems of parameterizing tools and harmonizing definitions, it also involves banks' very raison d'être more fundamentally. Economic literature grants banks two main reasons for existing. The first is related to the problems of informational asymmetry between lenders and borrowers which may make a direct transaction, like issuing securities, impossible on the market. The second concerns the liquidity service that banks are capable of providing to depositors, while also allowing borrowers long-term financing. This liquidity service provided by banks inevitably exposes them to the risk of illiquidity. As shown by the reference model established by Douglas Diamond and Philip Dybvig (1983), banks would not provide depositors with this assurance of liquidity if they were seeking perfect congruence for their liabilities and assets. In this case in fact, there would be no risk-sharing between depositors who have made short-term investments and those who have invested their money for the long haul. In addition, banks' contribution to long-term financing would be restricted to resources collected in the long term. This means that the illiquidity risk is a component of banking activity. It is banks' weakness as well as their justification for 
existing. Consequently, if banks' exposure to the risk of illiquidity is reduced, their capacity for transforming short-term resources collected from depositors into long-term financing for the economy is also reduced. This is what makes the "work site" such a difficult one: the illiquidity risk needs to be reduced without totally undermining banks' reason for being. By undermining banks' raison d'être, it is their contribution to long-term financing that is jeopardized.

Additionally, there is an interesting fact that stands out in the recent financial crisis. Save a few exceptions unworthy of note outside the case of the British bank Northern Rock, the illiquidity crunch did not come from a run on tellers' windows, but from a paralysis affecting the interbank market. The bailout plans implemented by governments and monetary authorities established a temporary public guarantee of interbank resources, among other measures. The question is now whether this public guarantee should not be permanently instituted so as to ensure the liquidity of the interbank market. Defending this option would however require two difficulties to be solved. The first one involves the moral hazard generated by any type of guarantee: banks could let down their guard toward their counterparties on the interbank market, thereby increasing the risk of systemic crisis. The second difficulty involves the "pricing" of the guarantee: a free guarantee would maximize the effect of moral hazard. Putting a price on the guarantee would mean being able to calibrate a sort of insurance premium paid by banks depending on the risk they present. The principle is similar to the one in force for guaranteeing deposits, which would have to be adapted here to guaranteeing interbank resources.

Lastly, the total paralysis of the interbank market in the autumn of 2008 can be largely explained by the pure and simple disappearance of structured product markets. These products were backed by mortgage or non-mortgage bank securities (Mortgage Backed Securities, Asset Backed Securities), or by other negotiable financial instruments (Collateralized Debt Obligations). All their investors were particularly fond of them before the subprime crisis, but they lost any and all value as soon as the default rate increased on subprime loans which were abundantly securitized and transformed into MBS. In this way, the securitization process at the origin of these products increasingly downplayed bank liquidity to the benefit of the banks' capacity to exchange or deposit non-standard assets in guarantee. These assets were negotiated and therefore also priced on over-the-counter markets. Here the issue at stake is the regulation of structured product markets. As soon as these products have been released from the pillory and the structuring activity has resumed, it would be advisable to think about the degree of standardization they should be subjected to and the conditions that should be laid down to regulate their exchange. One of the main initiatives, pointed out in the FMI's Financial Stability Report of April 2010, aims to place over-the-counter derivatives under the control of centralized clearing houses.

\section{Leverage ratio}

Theoretically, a solvency ratio weighted by banks' asset risks is more effective than a simple ceiling on asset leverage. This is what a number of authors endeavoured to demonstrate in the 
1980s and 1990s, with Koehn and Santomero 1980, Kim and Santomero 1988, Keeley and Furlong 1990, and Rochet 1992 discussing the regulation of capital in the context of the porffolio choice theory. They showed that a minimum non-weighted capital ratio, capital/ assets - i.e. the inverted equivalent of asset leverage, assets/capital - would lead banks to readjust their portfolios by selecting the most profitable, and therefore also necessarily the most risky, assets for a given capital regulatory cost. These authors deduced that weighting the ratio was essential and that the weighting factor should reflect the systematic risk $(\beta \mid$ of the assets. This work contributed to giving international standards on capital an important theoretical basis. Once the Cooke ratio was established at the end of the 1980s, regulators constantly refined the solvency ratio until they eventually achieved the closest approximation of the recommendations made in the economic literature.

One simple point was however neglected in both the theory and the practice of regulators: a carefully weighted capital ratio is no hindrance to operating with a high asset leverage value, much higher than the inverse of the weighted ratio. In other words, the increasing sophistication of the solvency standard did not keep certain banks from operating with an asset leverage, assets/capital, far higher than 12.5. ${ }^{2}$ Lastly, capital ratios have become asset allocation tools for banks rather than tools to reduce risk-taking, thereby weakening their role as warning signals.

The importance of leverage in the dynamic management of banks' balance sheets was also neglected. Now the adjustments brought about by seeking a target leverage value are a powerful factor in propagating crises by amplifying asset price variations. As explained by Tobias Adrian and Hyun Son Shin (2009), banks target an asset leverage value (e.g. a fixed ratio of assets/capitall, which in the event of a drop in securities prices on the market will prompt them to sell assets so as to re-establish their leverage at the target level. Symmetrically, in the event of an increase in asset prices, they will buy assets. In both cases targeting a leverage value will amplify the variation in asset prices. The fact that banks allow themselves to have a higher target leverage value in periods of growth and practice a lower one in economic slumps, or in other words the fact that the target is procyclic, compounds the problem even more.

Reducing the asset leverage value at a level that remains stable as has been the practice in Canada since the beginning of the 1980s might help limit the amplification effects on the variations in asset prices at the heart of crisis propagation. The recent financial crisis will in any case have revealed the need not to believe in the solvency ratio alone, however sophisticated it may be. As Jean-Charles Rochet and Matthias Dewatripont commented somewhat humorously during a conference devoted to The Future of Financial Regulation in January 2009: "It's better to be approximately right than accurately wrong!" Adapted to the subject, it means that a menu of simple ratios composing a set of warning signals is

2. The inverse of the regulatory capital ratio corresponds to an asset leverage level that should not exceed $1 / 8 \%=12.5$, with one sole difference, and it is a big one: in the regulatory ratio the assets are weighted according to their risk. When asset leverage is calculated taking an asset value that is non-weighted by risk, the result was between 30 and 50, or sometimes even higher in the case of certain banks before the financial crisis. 
better than a single Basel 2-type ratio. Even though this single ratio may very sophisticated, particularly when it is calculated on the basis of advanced internal ratings-based approach, it misses its objective which should be to limit risk-taking.

With a view to the upcoming Basel 3 agreements, a leverage ratio between assets on and off the balance sheet and hard capital was submitted by the Basel Committee for consultation. However, European banks tend to frown on this ratio because of the accounting distortions they suffer from in comparison with American banks which are authorized to practice clearing on derivatives and repos, thereby reducing the size of their balance sheets.

\section{The procyclicality issue}

There is an aspect of regulatory capital requirements that prudential authorities hardly attempted to correct at all before the crisis. These constraints accentuate the credit procyclicality. In times of sustained growth, prudential constraints are "toothless", and this means that banks comply with them without any trouble. It is a completely different story however when growth falls off and the situation on financial markets deteriorates. Banks then have to deal with an increasing default rate and the context is not propitious to obtaining added capital. In this case, regulatory capital requirements show their teeth and force banks to tighten credit even more than they would have without any constraints. In the same way, accounting standards that impose market price valuation on banks are necessarily procyclical, since compliance with these rules inflates the value of assets when things are humming along and reduces it sometimes drastically when the economy is in the doldrums.

The lack of attention paid to this procyclic problem can be explained largely by the "microprudential" nature of the approach taken by the supervisory authorities before the crisis. They concentrated on banks' individual risks, considering that this was the best way to ensure the stability of the financial system as a whole. This approach comes up against the fact that systemic risk is not a simple sum of individual risks. Phenomena such as contagion, propagation and amplification come into play in the event of systemic crisis. The financial crisis has shown the need for a more comprehensive approach to supervision that is termed macroprudential. Bank of International Settlements economists have long defended the merits of a macroprudential approach to supervision and the need to coordinate it with monetary policy, as evidenced by Claudio Borio's research (see for exemple Borio (2003), Borio and Ilhyock (2007), Borio (2010), and Annual reports of Bank for International Settlements). With a view to better preventing systemic crises, supervisory authorities will have to be more attentive to overall ups and downs from now on - particularly as regards credit and asset prices - in order to better detect incipient speculative bubbles. This will require new indicators, new instruments and even new institutions /see Geneva Reports on the World Economy $n^{\circ} 111$. As was recommended for Europe by the Larosière report, we can expect systemic risk committees to be developed within central banks, which will thereby be more involved in supervision. The instruments implemented will for the most part be based on capital surcharge for systemic banks and on contracyclic measures. The experience of Spain's banking sector had never inspired much of a following before the crisis. Yet, from 
the beginning of the 1990s, Spain set up a forward looking provisioning system that made banks set up reserve funds to offset credit risks, based not on actual losses, but much farther upstream on the statistical estimate of loss risks. So in times of strong growth when banks grant a lot of credit, they have to set aside large reserves to cover risks as a complement to the capital that they have to hold in proportion to their risky commitments. This system of dynamic provisioning is likely to have shored up the resilience of Spain's banking sector in a macroeconomic context that was hard hit by the economic crisis, with an unemployment rate to $15 \%$ in 2009 , severe shrinkage in consumption and investment.

The Basel Committee has taken on the issue and will make an effort in its future recommendations to favour the adoption of forward looking provisioning during the credit cycle. In the same perspective, the Basel Committee should recommend capital buffers to be set up by banks when the fundamentals are good so that they could be used when the economy deteriorates.

Liquidity ratios, leverage ratios and capital buffers will be at the heart of the Basel 3 agreements. These measures will have to offset the past inadequacies of prudential rules. Even so, they do not contradict pre-crisis prudential regulation: more capital and more reserves to prevent risks, probably with a new adjustment to the business cycle. This continuity may explain why Europeans are in favour of them. Americans, who are more critical of the Basel approach, have launched more radical proposals, such as taxation of banking operations or separation of banking and securities industries. In any case, the banking lobbies can be expected to wind up obtaining substantial flexibility.

\section{Internal Control: the Weak Points}

\section{Supervision and internal control: stronger together}

Basel 2 endorsed a strong relationship between banking regulation and internal control. In the 1990-2000 period, banks made progress in managing risks, e.g. ALM, scoring, data mining, value at risk models, etc., and rapidly sought to show off their risk management proficiency on the international scene. For example, at the beginning of the 1990s, the major international bank JP Morgan widely disseminated its Risk Metrics model used to evaluate market risks. Its lobbying campaign with the Basel Committee resulted in the Committee recognizing banks' capacity to assess their own capital needs by complying with certain conditions that were both quantitative - e.g. history, completeness and robustness and of the data base used - and qualitative - e.g. organization of risk management.

From Basel 2 agreements, what was common practice only for determining the coverage of market risks by capital was extended to all of the risks: credit, market and operational risks. Since then banks have had the choice between the standard regulatory model and two internal approaches, one of which is termed the "advanced internal ratings-based approach" and allows banks to calculate their capital coverage with the use of their models. 
There are several reasons why internal control and supervision should work together, that this is not only advisable but even necessary. First of all, linkage between them encourages a convergence of views between bank regulators and banks, and this convergence is indispensable to limit circumvention of regulations by banks. When the standards handed down by regulators are too far removed from standards that banks would apply to themselves, they will do everything in their power to get around the rules, by hook or by crook, with new products and new financial techniques for example. Securitization is a case in point here. Securitization began to develop in the 1990s at the time of the Cooke ratio, when banks came under the obligation of a regulatory ratio for capital based on a measurement of risks (ratio weighting) that was alien to banks' rationale. In retrospect, the development of securitization can be interpreted as a technique to circumvent standards on capital. By securitizing part of their assets, banks managed to reduce the denominator of the capital/ weighted assets ratio, thereby complying more readily with regulatory standards.

The greater the divergence of views and measurement modes between regulator and regulatee, the more regulation is condemned to a dialectic process of regulation - deregulation re-regulation, due to the strategies deployed by banks. Associating internal control and regulation entails greater convergence of views. In this way, it can reduce the urge for banks to sidestep regulations, since to a certain extent they are more involved in determining the standards they have to comply with. In addition, the genuinely closer relationship that this brings about between banks and regulators means greater information-sharing, which can allow regulators to keep abreast of the situation and adapt faster to developments in the banks' activity model. The regulators' response time to changes that characterize banking activity is a factor accentuating financial instability and the reduction in delays that can be expected from better communication of information would therefore be favourable lowering financial instability.

Therefore, the fault line does not reside in the linkage between internal control and supervision as such, but rather in the evolution of internal control during recent years.

\section{Externalisation of risk management}

Paradoxically, the management of banking risks, which is an important component of internal control, evolved in 1990-2000 by resorting increasingly to externalization techniques, i.e. the transfer of risks outside banks. Securitization along with credit derivatives allowed banks to transfer their risks to others and this resulted in a radical change in the banking model. Banks went from an originate to hold model, whereby they carried the risks that they originated, to an originate to distribute model, whereby they generated risks and then transferred them to other players who sold protection on the credit derivatives market or others who bought structured products such as ABS, MBS and CDO issued by securitization vehicles, or SPV. Initially, the change in model was not perceived as encouraging instability; on the contrary this transfer was expected to give rise to better risk-sharing and thereby give the financial system more resilience. The financial crisis proved just how wrong this misconception was. The explanation resides in the fact that risk-sharing among a larger 
number of bank and non-bank players brought about a dilution of risk control and follow-up. Additionally, the possibility to transfer risks was of course not neutral for risk-taking behaviour; banks took on more risks knowing that they could always transfer a large part of them.

Resorting to the externalization of banking risk management poses a double problem. First, unlike the process of externalization seen in other industries in 1990-2000, which generally involved the transfer of non-core activities, such as accounting and IT services, the externalization of services in the banking sector involved no less than the very heart of the sector's activity. The core of a bank's activity usually resides in its capacity to generate assets and therefore risks that the market could not have produced. Credit is asset specific to banks that they can generate due to their capacity to manage the phenomena of adverse selection and moral hazard that stem from informational asymmetries between lenders and borrowers. Now here is where the second part of the problem comes: when banks securitize credit or transfer their credit risks by buying a CDS on the credit derivatives market, the market winds up finding itself in the position of pricing what it was however incapable of originating. Starting with the principle that a large percentage of banking assets, credits in particular, get their value from the production of information by banks, these assets are finally emptied of their substance when they are transformed into market assets on the basis of the value that the market confers to them. These securitized debts have no fundamental value other than the value that bankers can confer to them. Their market value once securitized is based solely on their capacity to be exchanged. Should these exchanges ever be broken off for whatever reason and these securitized debts will no longer have any value. This is what happened on the market for MBS and ABS, structured products matched to mortgage or non-mortgage bank debts.

\section{Mathematical models and the illusion of control}

A good proportion of risk management has been externalized via securitization and credit derivatives. As for the "internalised" part, it is based on the use of mathematical financial models. It was the development of these models that allowed banks to take an active role in the supervisory system. Ample financial literature (see Kupiec (1995) in particular, or Berkowitz and O'Brien (2002)l pointed out the limits of value at risk models, which were used initially for the evaluation and coverage of market risks and then later in the same way for credit risks. Despite their limits, the models have been increasingly successful with bankers, to the point of giving them a dangerous "illusion of control".

These models have not only made bankers persist in the idea that they could control the risks associated with market activities, but they have also conferred a scientific basis to risk-taking. It has since become increasingly easier for the front office people, first and foremost those on the trading floor, to justify the complexity or even opacity of their operating strategies. However, when science is invoked, people are much readier to accept the fact that they do not understand. Let us consider a few examples: Neek Leeson, who made the Barings Bank lose 1.35 billion dollars, causing it to go into receivership under the Bank of England in late February 1995, before it was bought by the Dutch group ING Bank; Jérôme Kerviel, 
accused of fraud causing the Sociéte Générale to lose nearly 5 billion euros in January 2008; Bernard Madoff, whose crooked dealings were discovered in December 2008 and reportedly cost the investors who had entrusted him with their money no less that 50 billion dollars. They all found a way to bypass internal and even external control: internal risk control departments in the case of Leeson and Kerviel, as well as external control by the SEC, the American control authority for the stock exchange and investment funds, which held hearings on several occasions for Bernard Madoff. In addition, they achieved it all with disconcerting ease by systematically invoking a complex investment or coverage strategy based on a mathematical model. Our purpose here is not to dismiss the use of risk assessment models in banks but rather to suggest that they have patently contributed to the front office taking on an unprecedented ascendancy over the back office. As a result of "scientization", risk-taking jobs have become the "diva" jobs in banks. They demand the best qualified employees, the cream of the crop from the most reputed graduate schools and prestige engineering schools. They also offer fixed remuneration and variable bonuses higher than those paid to the members of the board! At the same time, the control functions, or back office, have been relegated to the back burner, even though they justify banks' reason for being. Banks have moved away from the role of delegated monitor that banking theory was fond of presenting to define them. Rethinking the business model of banks will require a reassessment of the risk-control management activity.

\section{Market Discipline: The Weak Points}

The banking regulatory system set up in the 1930s in the United States and in the post-war years in Europe and Japan had completely removed market mechanisms from the regulation of the banking sector, considering that the 1929 crisis had proof positive of their inefficiency. Administered regulation of the banking sector worked as long as economies remained closed and the activity of financial markets remained at a low level. The economic instability of the 1970s upset administered regulation however. Owing to the surplus balance of trade obtained by oil producing countries subsequent to the oil-price shocks of 1973 and 1979, capital flows started circulating again intensively. Meanwhile rising risks - interest and exchange rates - linked to the inflationist context of the period and to the collapse of the Bretton Woods system seriously encouraged the development of new financial products and served as a trampoline for capital markets. "Administered" banks then had to confront the competition from other domestic and foreign banks, as well as from booming financial markets favouring the boom of investment funds and other financial intermediaries. From then on, banking regulation had to adapt to this new context. Gradually, regulations that administered the banking sector, such as regulation of interest rates, control of credit, selected loans system, and exchange control, were suppressed in favour of new standards aiming to reduce risk-taking without keeping market mechanisms from participating in the regulation of the sector, i.e. free determination of prices and volumes of credits, by confronting supply and demand, and free competition, among others. 


\section{Market discipline levers}

Re-establishing market mechanisms reintegrated what is termed "market discipline" in the overall regulation of the sector. Market discipline includes all of the pressures that providers of funds can exert on banks' management. Several levers contribute to market discipline:

- The first resides in the informational content of market prices used as a basis for investors to decide to invest in banking securities. Market prices, and more particularly a bank's share prices or its bonds rates, supposedly supply information about the issuing bank's state of health.

- Communication of information by banks to their depositor and investor clients as well as to the regulator is yet another lever of market discipline to the extent that this information allows investors to better substantiate their financial decisions.

- Transparency of accounts is also an important condition for investors to be have clear views on whether to buy or sell the securities issued by banks, in other words to determine the amount and price of the resources they plan to deposit in or withdraw from a bank.

In the context of present-day supervision, market discipline has mainly been implemented based on three factors:

- Communication of information, which regulators have attempted to intensify. The third pillar of the Basel 2 agreements basically involves the requirement of financial communication. Two types of requirement can be distinguished: communication of information from banks to the regulator, or reporting, and communication that banks are held to provide to their clients, or disclosure.

- Ratings, which have begun to play a leading role in supervision. This information is extremely well monitored by investors and was included in supervision set-up via Basel 2. The standard method of determining the capital needed for credit risk coverage involves the use of external rating by rating agencies.

- Accounting standards in market value, as defined by the IASB, International Accounting Standards Board, in force since 2005. They aim to provide investors more transparent information on the balance sheets and results of the companies quoted. The IAS 39 standard applicable to banks makes them value a maximum number of items in their balance sheet and off of it at a fair value, the value dictated by the market, or to calculate a theoretical market value derived from a mathematical assessment model when this fair value does not exist.

\section{Problems and the way forward}

Here again, the problem does not reside in the fact of interlinking market discipline and regulation. If we accept the principle that no regulation mechanism is omniscient, then the association between them would even appear to be indispensable. Yet, the present-day levers of market discipline still did not help prevent the financial crisis, any more than prudential regulation or internal control. This leads us to wonder about the effectiveness of each of the levers used. 
Regarding the communication of information, which information should be transmitted, to whom and how often? If there is little risk that banks' reporting to supervisory authorities might have negative effects on financial stability - except maybe for the opportunity cost of the time devoted to reporting - the same can not be said of the disclosure requirements. Communicating too often to clients and investors may - and this is a well-known fact - set off an over-reaction in their midst and instead of correcting and stabilizing any difficulties disclosed, it could on the contrary reinforce them. Announcing poor results could for example cause a rush to sell a bank's securities. In this regard, reporting is seemingly easier to handle than disclosures.

This being true, the question that remains is what kind of information the regulator should require in order to ward off crises effectively. From this standpoint, the recent crisis has revealed the usefulness of "stress tests" which assess the impact of macroeconomic stress scenarios on the key variables and results of banking activity. In this way, the impact of a slowdown in economic growth, an increase in interest rates or a severe variability in exchange rates, can be assessed in terms of solvency, liquidity or profitability.

For quite some time, the nature of the information required belonged to a microprudential system and finally proved to be redundant when compared with the information destined to check conformity with prudential standards. During the crisis, stress tests were used mainly to designate which financial institutions should be recapitalized. Regular communication of stress tests helped monitor the resilience of institutions taken both individually and as a whole in dealing with the vagaries of the macroeconomic environment. In other words, the communication of the information required by the regulator could be a better warning signal within the context of a macroprudential system. This system consists in assessing and monitoring the systemic risk that the institutions could be exposed to, not only due to the contagion of individual difficulties but also owing to common exposure to macroeconomic shocks.

As was the case in previous crises, rating agencies were criticized - not without reason - for having been unable to warn investors of the upcoming crisis, although they were producing the information that was undoubtedly most closely followed by the market. Several factors explain this. First of all, rating methods have plainly not yet been adapted well enough to the sophistication of structured products and therefore transmitted biased information about product quality. Meanwhile, structured products are at the heart of the crisis. Insufficient development of rating methods is not unrelated to the high concentration of the rating market. There are three major agencies: Standard \& Poor's, Moody's and Fitch which divide up $90 \%$ of the market, with the remaining 10\% shared out among some 150 other very small agencies, so there is very little emulation and innovation among agencies. Additionally, rating agencies took part in structuring the products that they also rated, and received large commissions for their consulting and structuring services. This caused a conflict of interest likely to bode ill for impartial ratings. 
Until the recent crisis, even though rating agencies had become major players in the market discipline and supervision system, they were not closely monitored. In December 2004, the $\mathrm{OICV}$ laid down the main principles of good conduct, insisting on the quality and integrity of the rating procedure, the independence of agencies, the need to avoid conflicts of interest and the responsibilities of agencies toward issuers as well as investors. If the principles of the code are apparently moving in the right direction, it must be admitted that the code did not have much impact on the agencies' behaviour. A code of good conduct does not have the constraining nature of a regulation. Subsequent to the crisis meeting of the G20 in London, the member states of the European Union endorsed the principle of mandatory registration for agencies, forcing them to comply with rules of transparency and dissemination of information. We have not yet reached the stage of rules dictated on an international scale however. There is also a tricky problem to solve: it will be necessary to reconcile a stricter framework - the equivalent of entrance barriers to the ratings market - and the entrance of new agencies to dilute the concentration of the ratings market.

Lastly, the laudable intentions presiding over the implementation of accounting standards underestimated several detrimental effects. First of all, the standards aim to place a market value on assets which do not necessarily have one, even more so when the assets involved are for example credits originated by banks. The securitization of bank assets maintained the illusion that bank assets were finally not different from a portfolio of negotiable assets that could be associated with a market value. However, during the crisis the products matched to bank debts suddenly became illiquid, in other words, impossible to trade. This episode demonstrated that the application of market value accounting was heavily dependent on the liquidity of assets. Secondly, during the crisis, market value accounting amply precipitated the sale of assets and contributed to the contagion and amplification of the crisis. This amplification process corresponds to what we discussed earlier on the subject of target leverage: market value accounting forces banks to realize immediately when their asset value varies and to adapt to the situation. When they realize that the value of their assets has fallen, with the resulting drop in the value of their capital - assuming that the value of debt does not vary - banks must react to an increase in asset leverage. This is what they do when they sell assets, and this reinforces the drop in asset value and so on and so forth. More broadly, it is the procyclic effect of these accounting standards which is in question, since they tend to inflate banks' asset purchases and good results in the good times and precipitate asset sales and lower results when the going gets rough.

During the crisis, a rearrangement of accounting standards proved to be necessary. Announced as a temporary measure initially, it will finally be imposed definitively. Regarding the principle, the idea is to authorize an accounting measure that is an alternative to "fair value", when the market no longer provides normal asset liquidity conditions. However, an important point was emphasized by Didier Marteau and Pascal Morand in their report (2010): the choice must not be left to the discretion of the players, but should come from a relevant public authority. In short, the idea is not to break the thermometer that constitutes market value accounting, but to know when to use it and to have another measure on 
standby when the market is no longer in a position to provide the realistic price, submitting the decision to a public authority.

\section{Conclusion}

Above and beyond attempting to show that we do not advocate breaking up the big three, but rather reinforcing them in each of their axes, i.e. prudential regulation, internal control and market discipline, the question arises of the institutions that financial regulation functions around. Despite the crisis and the reforms that it helped launch, there has not been much institutional evolution on an international scale. Most supervisory structure reforms have been strictly national (see the Deletré Report and the Report of the Group of 30). France and Belgium have for example begun reforms of their supervisory systems which date back to before the crisis. These two countries are planning to move toward a twin-peaks organization: supervision of financial go-betweens, such as banks, insurance, securities managers, under the control of a single authority, with monitoring of markets and of the conduct of business under that of a second authority. In this regard, the crisis seems to have highlighted the need not to mix up prudential supervision and conduct of business, but to make the protection of financial services consumers a fully-fledged objective in itself. The crisis has also shown the need for a close relationship between the central bank and financial supervisors. Integrated systems, with a single supervisor, had not taken this constraint into much account, in particular, the British model, which was the object of much criticism. In Great Britain and Germany, the central bank should see its role developing in prudential supervision. The issue is more heavily debated in the United States, since the increased influence of the Fed in supervision raises fears of too highly concentrated power.

Therefore the crisis caused or accelerated the reforms in the structure of the supervisory system but on a national level; internationally evolution is necessarily slower. Certainly, the IMF saw its role in financial stability reaffirmed and the Financial Stability Forum was rebaptized the "Financial Stability Council". Still however, a host of national supervisory authorities will have to continue to coordinate their action as well as they can, attending the meetings of international and European consultancy committees. As of yet, there has been no global financial regulation in a global world of finance, but a step has perhaps been taken in Europe thanks to the recommendations made in the report of the group presided over by Jacques de Larosière. The three European national regulators' coordination committees for the banking sector (CESB), the insurance sector (CEIOPS) and the securities market sector (CESR), that were set up in the context of the Lamfalussy procedure will be granted their own powers, which may eventually turn them into genuine European regulation authorities. 


\section{REFERENCES}

Adrian, T., Shin, H.S., 2009. Liquidity and leverage federal reserve board of New York Staff Report 328. Available at SSRN: http://ssrn.com/abstract=1 139857.

Berkowitz, J.,O'Brien, J., 2002. How accurate are value-at-risk models at commercial banks?, Journal of Finance 57, 1093-1 111 .

Borio, C., 2010. Implementing a macroprudential framework: Blending boldness and realism, keynote address for the BIS-HKMA research conference on Financial Stability: Towards a Macroprudential Approach, Honk Kong SAR, 5-6 July 2010. Available at Bank for International Settlements web site: hitp:// www.bis.org/repofficepubl/hkimr201007.12c.pdf Borio, C., 2003. Towards a macroprudential framework for financial supervision and regulation? (February 2003). BIS Working Paper 128. Available at SSRN: hitp://ssrn.com/abstract=841306.

Borio, C., Ihyock S., 2007. What can (macro-l prudential policy do to support monetary policy? (December 2007). BIS Working Paper No. 242. Available at SSRN: http://ssrn.com/abstract=1 120287

Diamond, D.W., Dybvig, P., 1983. Bank runs, deposit insurance and liquidit, Journal of Political Economy, 91.

Furlong, F.T., Keeley, M.C., 1990. A reexamination of mean-variance analysis of bank capital regulation, Journal of Banking and Finance, 14.

Goodhart, C., 2008. La gestion du risque de liquidité, Banque de France, Revue de la stabilité financière 11, février 2008

Kim, D., Santomero, A.M., 1988. Risk in banking and capital regulation, The Journal of Finance, XLII, $n^{\circ} 5$.

Koehn, M., Santomero A.M., 1980. Regulation of bank capital and porffolio risk, The Journal of Finance, 35.

Kupiec, P., 1995. Techniques for verifying the accuracy of risk measurement models, Journal of Derivatives 3, 73-84.

Rochet, J.C., 1992. Capital requirements and the behaviour of commercial banks, European Economic Review, 36. 


\section{REPORTS ON FinANCIAL Regulation}

Bank for International Settlements 2010. 80 Annual Report, 28 June 2010.

Basel Committee on Banking Supervision 2009. Consultative Document: Strengthening the resilience of the banking sector, December 2009.

Deletré, B., 2009. Rapport de la mission de réflexion et de propositions sur l'organisation et le fonctionnement de la supervision des activités financières en France, janvier 2009.

Geneva Reports on the World Economy ICMB, CEPR nº 1 1, july 2009.

Brunnermeier, M., Crockett A., Goodhart, C., Persaud, A.D., Shin, H., 2009. The fundamental principles of financial regulation.

Group of thirty: Financial Reform. A framework for financial stability January 2009. The structure of financial supervision. Approaches and challenges in a global marketplace. A report of the G30 Regulatory Systems Working Group, October 2008.

International Monetary Fund, 2010. Global Financial Stability Report. Meeting new challenges to stability and building a safer system, April 2010.

Larosière J. de (chaired by) 2009. The high-level group of financial supervision in the EU, Report, Brussels, 25 February.

Marteau, D., Morand, P., 2010. Normes comptables et crise financière : propositions pour une réforme du système de régulation comptable, rapport officiel, ESCP Europe, Documentation française, février 2010. 
